\title{
Communication
}

\section{Superior performance of iridium supported on rutile titania for the catalytic decomposition of $\mathrm{N}_{2} \mathrm{O}$ propellants}

\author{
Shuang Liu a,b,t, Nanfang Tang a,t, Qinghao Shang a,c, Chuntian Wu a, Guoliang Xu a, Yu Cong a,* \\ a Dalian Institute of Chemical Physics, Chinese Academy of Sciences, Dalian 116023, Liaoning, China \\ b Shanghai Institute of Organic Chemistry, Chinese Academy of Sciences, Shanghai 200032, China \\ c University of Chinese Academy of Sciences, Beijing 100049, China
}

\section{A R T I C L E I N F}

\section{Article history:}

Received 12 March 2018

Accepted 9 April 2018

Published 5 July 2018

\section{Keywords:}

Heterogeneous catalysis

Nitrous oxide

Catalytic decomposition

Iridium catalyst

Titania

\begin{abstract}
A B S T R A C T
$\mathrm{N}_{2} \mathrm{O}$ is a promising green propellant and exhibits great potential for satellite propulsion systems. It is difficult for catalytic decomposition, which is an important way to initiate the propulsion process, to occur at temperatures below $600{ }^{\circ} \mathrm{C}$ due to the high activation energy of $\mathrm{N}_{2} \mathrm{O}$. In this work, we report an Ir supported on rutile $\mathrm{TiO}_{2}\left(\mathrm{Ir} / \mathrm{r}-\mathrm{TiO}_{2}\right)$ catalyst which exhibits a fairly high activity for high-concentration $\mathrm{N}_{2} \mathrm{O}$ decomposition. HAADF-STEM, $\mathrm{H}_{2}$-TPR, and XPS results indicate that highly dispersed Ir particles and improved oxygen mobility on the $\mathrm{Ir} / \mathrm{r}-\mathrm{TiO}_{2}$ could facilitate the decomposition of $\mathrm{N}_{2} \mathrm{O}$ and desorption of the adsorbed oxygen. Bridge-bonded peroxide intermediates were observed with in-situ DRIFT and herein, a detailed decomposition route is proposed.
\end{abstract}

(C) 2018, Dalian Institute of Chemical Physics, Chinese Academy of Sciences. Published by Elsevier B.V. All rights reserved.
Nitrous oxide $\left(\mathrm{N}_{2} \mathrm{O}\right)$ is a promising green propellant for small satellites because of its many advantages, such as system simplicity, multiple propulsion modes, extremely low toxicity, and compatibility with common construction materials. The direct decomposition of $\mathrm{N}_{2} \mathrm{O}$ to $\mathrm{N}_{2}$ and $\mathrm{O}_{2}$ is the most effective method for propulsion applications. However, although this process is thermodynamically favorable, it does not readily occur at temperatures below $600{ }^{\circ} \mathrm{C}$ due to its high activation energy of about $250 \mathrm{~kJ} \mathrm{~mol}^{-1}$ [1]. This energy requirement cannot be satisfied by the energy supply systems of small satellites. Therefore, there is an urgent need to develop appropriate decomposition catalysts with high activity at low temperatures as well as good stability at high temperatures.

A wide variety of catalysts have been developed for the di- rect decomposition of $\mathrm{N}_{2} \mathrm{O}$, e.g. pure and mixed oxides, transition metal-exchanged zeolites, and supported metal catalysts [2-4]. For example, a cobalt spinel catalyst which was promoted by cerium exhibited a high activity for $\mathrm{N}_{2} \mathrm{O}$ decomposition, completely decomposing $\mathrm{N}_{2} \mathrm{O}$ at a temperature below $200{ }^{\circ} \mathrm{C}$ [5]. The Fe-ZSM catalyst was highly active and stable for the removal of $\mathrm{N}_{2} \mathrm{O}$ in simulated tail-gas from nitric acid plants [6]. Unfortunately, these catalysts were only used for the decomposition of low-content $\mathrm{N}_{2} \mathrm{O}$. When these catalysts are applied for the decomposition of high concentrations of $\mathrm{N}_{2} \mathrm{O}$, their activities are not high enough to reduce the external energy required to initiate $\mathrm{N}_{2} \mathrm{O}$ decomposition. In recent years, some attempts have been made to find high-activity catalysts by combining noble metals with thermally stable supports. For example, mul-

\footnotetext{
* Corresponding author. E-mail: ycong@dicp.ac.cn

${ }^{\dagger}$ These authors contributed equally to this work.

This work was supported by the National Natural Science Foundation of China $(21476229,21376236,21503264)$.

DOI: 10.1016/S1872-2067(18)63077-3 | http://www.sciencedirect.com/science/journal/18722067 | Chin. J. Catal., Vol. 39, No. 7, July 2018
} 
lite and $\mathrm{Al}_{2} \mathrm{O}_{3}-\mathrm{SiO}_{2}$-supported rhodium catalysts were highly active at about $350{ }^{\circ} \mathrm{C}[1,7]$. Iridium-substituted $\mathrm{Al}_{2} \mathrm{O}_{3}$ and hexa-aluminates have shown high activities and excellent thermal stabilities $[8,9]$. Nevertheless, in order to improve the specific activity, i.e. the degree of utilization of the noble metal, and to explore novel catalyst systems, further improvements of the catalytic performance are persistent pursuits.

Titania is applied in a wide range of catalysis fields, especially photocatalysis [10] and gold catalysis [11]. It is well known that titania is relatively easy to reduce and forms oxygen vacancies or other defect sites. These vacancies and defects may influence and even dictate the surface chemistry of titania, such as providing or accepting electronic charge for oxygen-related reactions [12]. In the direct decomposition of $\mathrm{N}_{2} \mathrm{O}$, oxygen is produced in large quantities and its desorption has been identified as the rate-determining step [13]. Hence, the facile reducibility of titania may be helpful to promote the transfer of oxygen and accelerate the decomposition of $\mathrm{N}_{2} \mathrm{O}$ at low reaction temperatures. In addition, $\mathrm{IrO}_{2}$ has the same crystal structure as rutile $\mathrm{TiO}_{2}$, a thermodynamically stable phase of titania's crystallographic polymorphs. The close cell parameters and comparable Ir-O and Ti-O distances were shown to be able to stabilize highly dispersed Ir species and contribute to the catalytic activity of gold particles that were deposited on top of the $\mathrm{IrO}_{2}$, which was directly contacted with $\mathrm{TiO}_{2}$, for $\mathrm{CO}$ oxidation [14]. This may also be beneficial for the decomposition of $\mathrm{N}_{2} \mathrm{O}$. In our previous work, a significant improvement of the catalytic activity for $\mathrm{N}_{2} \mathrm{O}$ decomposition was observed for a $\mathrm{TiO}_{2}$-promoted $\mathrm{Ir} / \mathrm{Al}_{2} \mathrm{O}_{3}$ catalyst [15]. With the aim of developing a more efficient catalyst and revealing its intrinsic characteristics, $\mathrm{TiO}_{2}$-supported Ir catalysts were prepared and applied for the direct decomposition of highly concentrated $\mathrm{N}_{2} \mathrm{O}$.

Herein, rutile-phase titania $\left(\mathrm{r}-\mathrm{TiO}_{2}\right)$ was selected to prepare an Ir-supported catalyst ( $\left.\mathrm{Ir} / \mathrm{r}-\mathrm{TiO}_{2}\right)$ using a homogeneous deposition precipitation (HDP) process. For comparison, $\gamma-\mathrm{Al}_{2} \mathrm{O}_{3}$, anatase titania, and P25-supported Ir catalysts were also prepared following the same procedures (labelled as $\mathrm{Ir} / \gamma-\mathrm{Al}_{2} \mathrm{O}_{3}$, $\mathrm{Ir} / \mathrm{a}-\mathrm{TiO}_{2}$, and $\left.\mathrm{Ir} / \mathrm{P} 25\right)$. The detailed preparation processes and physical properties are included in the Supporting Information (SI). The activity evaluation was carried out in a fixed-bed flow quartz reactor. Fig. 1 shows a comparison of the catalytic activities of the different Ir catalysts (Ir loading $2 \mathrm{wt} \%$ ) as a function of the reaction temperature. All the catalysts, though lower in Ir content when compared with those in our previous study (at least $5 \mathrm{wt} \%$ in general), exhibited high activities, and all were able to completely decompose $\mathrm{N}_{2} \mathrm{O}$ below $400{ }^{\circ} \mathrm{C}$ (Table S1). This may be correlated with the high Ir utilization that resulted from the HDP preparation process that was used in this study. $\mathrm{Ir} / \mathrm{r}-\mathrm{TiO}_{2}$ showed the highest activity, with a light-off temperature $\left(T_{50}\right)$ of $265{ }^{\circ} \mathrm{C}$ (the temperature at $50 \% \mathrm{~N}_{2} \mathrm{O}$ conversion), which was more than $70{ }^{\circ} \mathrm{C}$ lower when compared with the reference catalyst, $\mathrm{Ir} / \gamma-\mathrm{Al}_{2} \mathrm{O}_{3}\left(T_{50}=339{ }^{\circ} \mathrm{C}\right) . \mathrm{Ir} / \mathrm{a}-\mathrm{TiO}_{2}$ and Ir/P25 also showed very high activities, with $T_{50}$ values of 280 and $289^{\circ} \mathrm{C}$, respectively. These results suggest that $\mathrm{TiO}_{2}$, particularly in the rutile form, plays an important role in the direct decomposition of $\mathrm{N}_{2} \mathrm{O}$. The effect of Ir loading was also evaluated. As illustrated in Fig. S1, the $\mathrm{N}_{2} \mathrm{O}$ decomposition activity

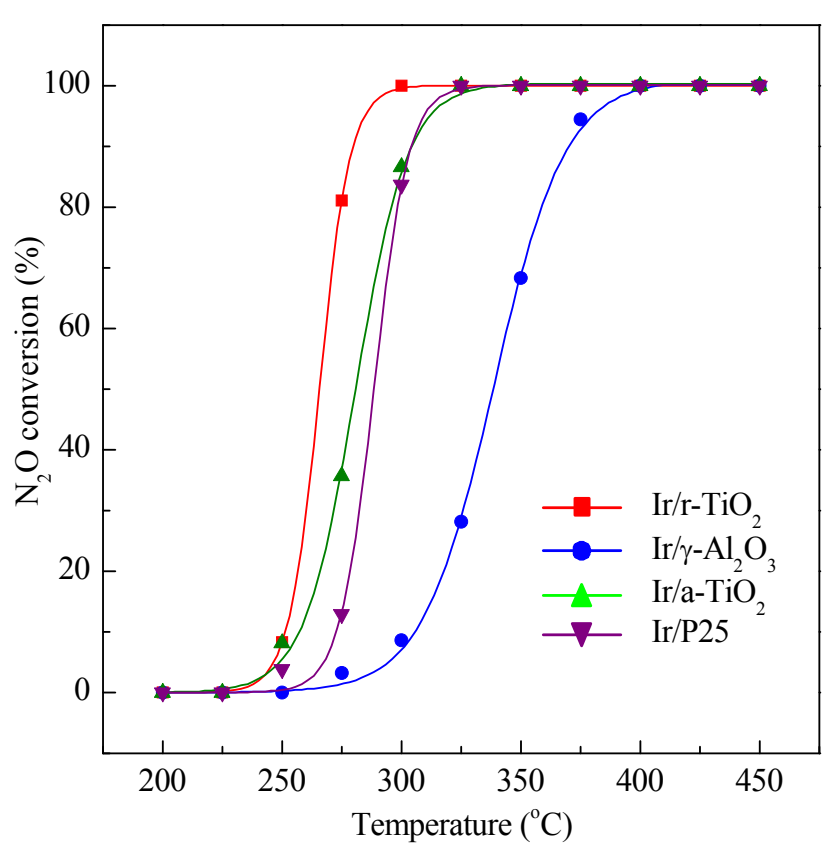

Fig. 1. $\mathrm{N}_{2} \mathrm{O}$ conversion as a function of temperature for the Ir catalysts with different supports.

increased with higher Ir loading. When the Ir loading was $0.1 \%$, the catalyst achieved a high activity $\left(T_{50}=338^{\circ} \mathrm{C}\right)$, equivalent to that of $\mathrm{Ir} / \gamma-\mathrm{Al}_{2} \mathrm{O}_{3}$. When the Ir loading was $5 \%$, the catalyst possessed a $T_{50}$ of $261{ }^{\circ} \mathrm{C}$, and exhibited the lowest temperature for $50 \% \mathrm{~N}_{2} \mathrm{O}$ conversion. This trend implies that the Ir species act as the active sites in this catalytic combination. We also found that the pre-treatment with hydrogen significantly impacted the catalytic performance of $\mathrm{Ir} / \mathrm{r}-\mathrm{TiO}_{2}$. As shown in Fig. S2, the $\mathrm{Ir} / \mathrm{r}-\mathrm{TiO}_{2}$ that was pre-reduced with $\mathrm{H}_{2}$ at $400{ }^{\circ} \mathrm{C}$ exhibited a higher catalytic activity than that without the pre-reduction. A long-term test at $300{ }^{\circ} \mathrm{C}$ was also performed with the $\mathrm{Ir} / \mathrm{r}-\mathrm{TiO}_{2}$ catalyst. During the 5,000-min test, the catalyst retained a high, but weakly decaying, $\mathrm{N}_{2} \mathrm{O}$ conversion (Fig. S3).

The Brunauer-Emmett-Teller (BET) surface area of $\mathrm{Ir} / \mathrm{r}-\mathrm{TiO}_{2}\left(6 \mathrm{~m}^{2} / \mathrm{g}\right)$ was much lower than that of $\mathrm{Ir} / \gamma-\mathrm{Al}_{2} \mathrm{O}_{3}(40$ $\mathrm{m}^{2} / \mathrm{g}$ ), indicating that the surface area is not the primary factor for the high activity in $\mathrm{N}_{2} \mathrm{O}$ decomposition (Table S2). The state of Ir was then measured with high-angle annular dark-field scanning transmission electron microscopy (HAADF-STEM) and X-ray diffraction (XRD). It can be seen, in Fig. 2(a) and (b), that the $\mathrm{Ir}$ species were highly dispersed on $\mathrm{Ir} / \mathrm{r}-\mathrm{TiO}_{2}$ with an average diameter of $1.25 \mathrm{~nm}$ (Fig. 2(c)). In contrast, agglomerated three-dimensional (3D) Ir nanoparticles were present on $\mathrm{Ir} / \gamma-\mathrm{Al}_{2} \mathrm{O}_{3}$ (Fig. S4). This is consistent with the XRD results (Fig. 2(d)). No diffraction peaks for the iridium species were observed for $\mathrm{Ir} / \mathrm{r}-\mathrm{TiO}_{2}$, but obvious iridium diffraction peaks were observed for $\mathrm{Ir} / \gamma-\mathrm{Al}_{2} \mathrm{O}_{3}$. The detailed Ir dispersions were also examined with pulse chemisorption of $\mathrm{CO}$, as presented in Table S2, and these results further verified the above observations. Thus, the high dispersity of the $\mathrm{Ir}$ species on $\mathrm{Ir} / \mathrm{r}-\mathrm{TiO}_{2}$ is believed to be responsible for the high catalytic activity of $\mathrm{N}_{2} \mathrm{O}$ decomposition. 

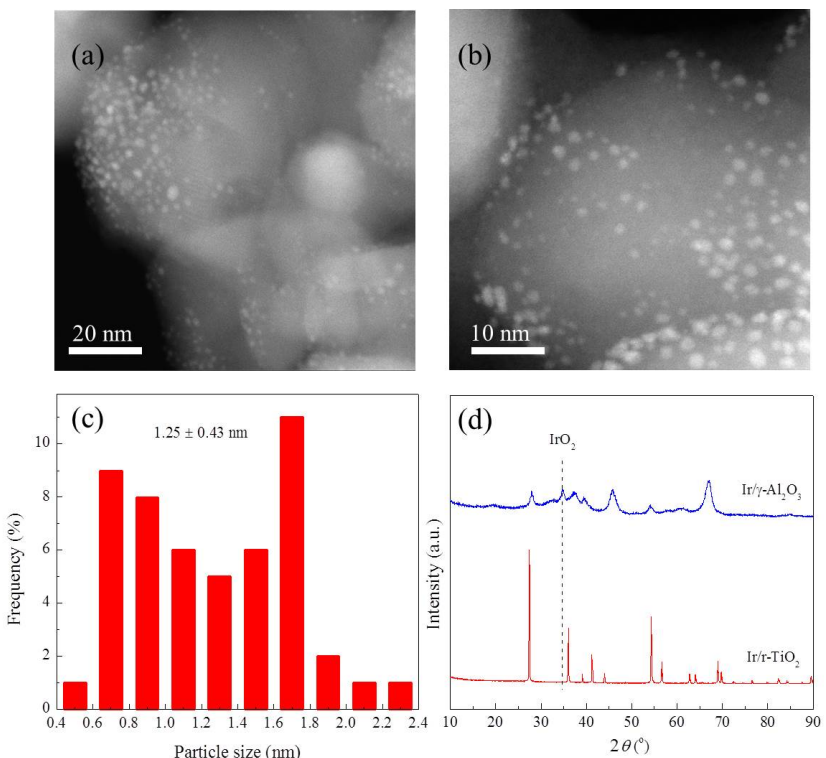

Fig. 2. (a, b) HAADF-STEM images of the $\mathrm{Ir} / \mathrm{r}-\mathrm{TiO}_{2}$; (c) Histogram of the size distributions of $\mathrm{Ir} / \mathrm{r}-\mathrm{TiO}_{2}$; (d) XRD patterns of $\mathrm{Ir} / \mathrm{r}-\mathrm{TiO}_{2}$ and $\mathrm{Ir} / \gamma-\mathrm{Al}_{2} \mathrm{O}_{3}$.

An $\mathrm{H}_{2}$-TPR experiment was performed to demonstrate the redox properties of the Ir species. Fig. 3(a) shows that $\mathrm{Ir} / \gamma-\mathrm{Al}_{2} \mathrm{O}_{3}$ exhibited a well-defined TPR peak at $218{ }^{\circ} \mathrm{C}$ and a weak shoulder peak at $345{ }^{\circ} \mathrm{C}$, which can be attributed to the reduction of $\mathrm{IrO}_{2}$ to $\mathrm{Ir}^{0}$ with a large particle size [16]. Whereas for $\mathrm{Ir} / \mathrm{r}-\mathrm{TiO}_{2}$, two peaks centered at about 112 and $220^{\circ} \mathrm{C}$ were observed. The low-temperature shift of the reduction peaks suggests that the $\mathrm{Ir} / \mathrm{r}-\mathrm{TiO}_{2}$ catalyst is more easily reduced when compared with the $\mathrm{Ir} / \gamma-\mathrm{Al}_{2} \mathrm{O}_{3}$ catalyst. Furthermore, Fig. 3(a) also shows that the $\mathrm{H}_{2}$ consumption peak for $\mathrm{Ir} / \mathrm{r}-\mathrm{TiO}_{2}$ in the temperature range of 50 to $400{ }^{\circ} \mathrm{C}$ was significantly larger than that for $\mathrm{Ir} / \gamma-\mathrm{Al}_{2} \mathrm{O}_{3}$. This suggests that not only Ir oxides, but also $\mathrm{Ti}^{4+}$ species are partially reduced due to the typical spillover effect.

X-ray photoelectron spectroscopy (XPS) spectra were recorded to investigate the electronic state of the Ir catalysts after reduction. As illustrated in Fig. $\mathrm{S} 5, \mathrm{Ir} / \gamma-\mathrm{Al}_{2} \mathrm{O}_{3}$ had a binding

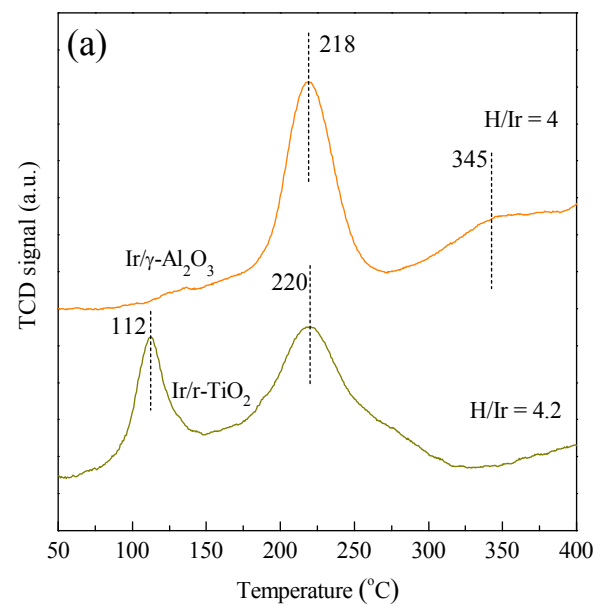

Fig. 3. (a) $\mathrm{H}_{2}$-TPR profiles of the $\mathrm{Ir} / \mathrm{r}-\mathrm{TiO}_{2}$ and $\mathrm{Ir} / \gamma-\mathrm{Al}_{2} \mathrm{O}_{3}$ catalysts; (b) $\mathrm{O} 1 \mathrm{~s}$ XPS spectra of the $\mathrm{Ir} / \mathrm{r}-\mathrm{TiO} \mathrm{O}_{2}$ and $\mathrm{Ir} / \gamma-\mathrm{Al}_{2} \mathrm{O}_{3}$ catalysts. energy of $60.6 \mathrm{eV}\left(\operatorname{Ir} 4 f_{7 / 2}\right)$ after reduction at $400{ }^{\circ} \mathrm{C}$, indicating that Ir is in a metallic state after the reduction treatment [8]. Compared to $\mathrm{Ir} / \gamma-\mathrm{Al}_{2} \mathrm{O}_{3}$, the $\mathrm{Ir} 4 f_{7} / 2$ binding energy for $\mathrm{Ir} / \mathrm{r}-\mathrm{TiO}_{2}$ showed a $0.3 \mathrm{eV}$ shift to $60.3 \mathrm{eV}$, indicating that the Ir species in $\mathrm{Ir} / \mathrm{r}-\mathrm{TiO}_{2}$ were rich in electrons. A weak $\operatorname{Ir} 4 f_{7 / 2}$ peak at $61.2 \mathrm{eV}$ was assigned to partially oxidized $\mathrm{Ir}^{\delta+}$ species, which were generated from the electronic transfer between the partially reduced $\mathrm{TiO}_{2}$ and the iridium particles [17]. The 01s XPS spectra are presented in Fig. 3(b). Ir $/ \gamma-\mathrm{Al}_{2} \mathrm{O}_{3}$ showed a strong $01 s$ peak centered at $531.3 \mathrm{eV}$, which can be fitted by two peaks with the binding energies of 530.9 and $531.9 \mathrm{eV}$. These were assigned to the lattice oxygen of $\mathrm{Al}_{2} \mathrm{O}_{3}$ and $\mathrm{OH}$ species, respectively [18]. $\mathrm{Ir} / \mathrm{r}-\mathrm{TiO}_{2}$ showed two separate $01 \mathrm{~s}$ peaks centered at 529.7 and $532.2 \mathrm{eV}$ which may be attributed to lattice oxygen $\mathrm{O}^{2-}$ from the metal oxides (labelled as $\mathrm{O}_{\alpha}$ ) and adsorbed oxygen belonging to a hydroxyl-like group (labelled as $O_{\beta}$ ), respectively [19]. The surface chemisorbed oxygen, $O_{\beta}$, has been reported to be highly active in oxygen-containing reactions due to its higher mobility over lattice oxygen [19]. Compared to the $\mathrm{OH}$ species of $\mathrm{Ir} / \gamma-\mathrm{Al}_{2} \mathrm{O}_{3}$, the adsorbed oxygen on the $\mathrm{Ir} / \mathrm{r}-\mathrm{TiO}_{2}$ surface exhibited a high binding energy transfer, indicating that these oxygen species have a higher mobility than the $\mathrm{OH}$ species. Therefore, the electron-rich, easy electronic transfer of the Ir species and the existence of high-mobility oxygen species on the $\mathrm{Ir} / \mathrm{r}-\mathrm{TiO}_{2}$ surface could be considered as the cause which promotes the direct decomposition of $\mathrm{N}_{2} \mathrm{O}$.

As shown in the in situ $\mathrm{N}_{2} \mathrm{O}$-DRIFT spectra which were collected at different temperatures (Fig. 4), the adsorption of $\mathrm{N}_{2} \mathrm{O}$ onto $\mathrm{Ir} / \mathrm{r}-\mathrm{TiO}_{2}$ produced two main vibrations in the range of 2100-2400 $\mathrm{cm}^{-1}$ and $1273-1302 \mathrm{~cm}^{-1}$. The former bands, in the range of $2100-2400 \mathrm{~cm}^{-1}$, can be attributed to the $\mathrm{N}-\mathrm{N}$ stretching frequency of the $\mathrm{N}_{2} \mathrm{O}$ that was adsorbed onto the Ir species. The latter bands, in the range of $1273-1302 \mathrm{~cm}^{-1}$, are attributed to the $\mathrm{N}-\mathrm{O}$ stretching modes with end-on oxygen coordinated with the metal species (M-O-NN) [20]. With increased reaction temperatures, the intensity of the two aforementioned bands decreased, suggesting that the $\mathrm{O}-\mathrm{N}$ bonds of the adsorbed $\mathrm{N}_{2} \mathrm{O}$ onto the Ir species were broken. This may be correlated with the weakening of the $\mathrm{O}-\mathrm{N}$ bond that is induced

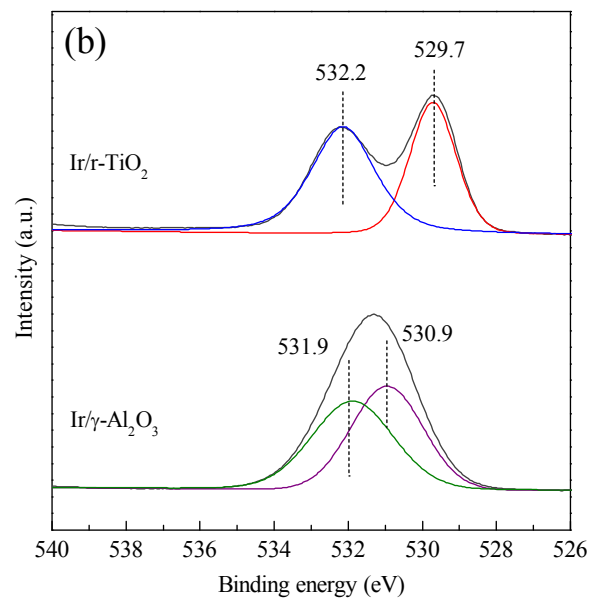




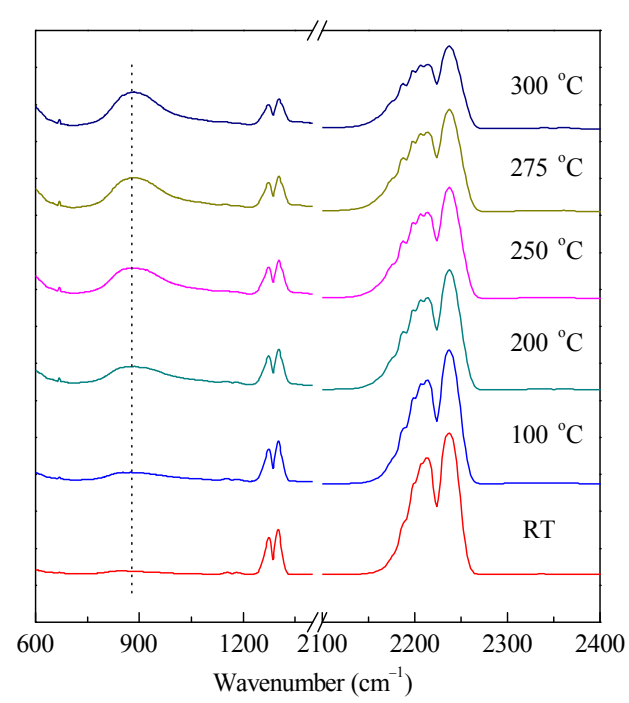

Fig. 4. In situ DRIFT spectra of $\mathrm{Ir} / \mathrm{r}-\mathrm{TiO}_{2}$ exposed to $\mathrm{N}_{2} \mathrm{O}$ at different temperatures following reduction.

by charge transfer involving the LUMO of $\mathrm{N}_{2} \mathrm{O}$ and the $n+1 \mathrm{~s} / n \mathrm{~d}$ orbital rehybridization at the Ir centers along with the additional interactions between the $\mathrm{N}_{2} \mathrm{O}$ HOMO and the metal $n \mathrm{~d}$ orbitals [21]. It should be noted that a new band at $882 \mathrm{~cm}^{-1}$, attributed to the stretching mode of the bridge-bonded peroxides, appeared and increased at higher temperatures. This further indicates that peroxides are intermediate species for the $\mathrm{N}_{2} \mathrm{O}$ decomposition [22,23].

From these findings, a plausible decomposition process of $\mathrm{N}_{2} \mathrm{O}$ can be proposed as follows. First, nitrous oxide chemisorbs and dissociates to form gaseous nitrogen and an oxygen adatom on the surface of the iridium adjacent to the $\mathrm{TiO}_{2}$. Second, the oxygen adatom transfers to a higher-mobility oxygen intermediate that is chemisorbed onto rutile $\mathrm{TiO}_{2}$. Then, the nitrous oxide is further adsorbed, another oxygen adatom combines with the chemisorbed oxygen intermediate, and transforms into a diatomic $\mathrm{O}_{2}{ }^{2-}$ ion via a dynamic transfer process.
Finally, the molecular oxygen desorbs from the rutile $\mathrm{TiO}_{2}$ surface and releases an oxygen vacancy.

$$
\begin{gathered}
\mathrm{N}_{2} \mathrm{O}(\mathrm{g})+\mathrm{Ir} / \mathrm{TiO}_{2} \rightarrow \mathrm{NN}-\mathrm{O}-\mathrm{Ir} / \mathrm{TiO}_{2} \rightarrow \mathrm{N}_{2}(\mathrm{~g})+\mathrm{O}-\mathrm{Ir} / \mathrm{TiO}{ }_{2} \\
\text { O-Ir } / \mathrm{TiO}_{2} \rightarrow \mathrm{Ir}^{\delta+} / \mathrm{TiO}_{2}-\mathrm{O}^{-} \\
\mathrm{N}_{2} \mathrm{O}(\mathrm{g})+\mathrm{Ir}^{\delta+} / \mathrm{TiO}_{2}-\mathrm{O}^{-} \rightarrow \mathrm{NN}-\mathrm{O}-\mathrm{Ir}^{\delta+} / \mathrm{TiO}_{2}-\mathrm{O}^{-} \rightarrow \\
\mathrm{N}_{2}(\mathrm{~g})+\mathrm{O}-\mathrm{Ir}^{\delta+} / \mathrm{TiO}_{2}-\mathrm{O}^{-} \\
\text {O-Ir }{ }^{\delta+} / \mathrm{TiO}_{2}-\mathrm{O}^{-} \rightarrow \mathrm{Ir}^{\delta+} / \mathrm{TiO}_{2}-\mathrm{O}_{2}{ }^{2-} \\
\mathrm{Ir}^{\delta+} / \mathrm{TiO}_{2}-\mathrm{O}_{2}{ }^{2-} \rightarrow \mathrm{O}_{2}(\mathrm{~g})+\mathrm{Ir} / \mathrm{TiO}_{2}
\end{gathered}
$$

In conclusion, a rutile $\mathrm{TiO}_{2}$-supported Ir catalyst was prepared via a HDP process and exhibited a high catalytic activity for the direct decomposition of $\mathrm{N}_{2} \mathrm{O}$. HAADF-STEM, $\mathrm{H}_{2}$-TPR, and XPS measurements confirm that highly dispersed iridium is supported on the rutile titania and the improved oxygen mobility on $\mathrm{Ir} / \mathrm{r}-\mathrm{TiO}_{2}$ can facilitate the decomposition of $\mathrm{N}_{2} \mathrm{O}$ and the transfer of intermediate oxygen species. Bridge-bonded peroxide intermediates were observed through in situ $\mathrm{N}_{2} \mathrm{O}$-DRIFT, and a detailed catalytic direct decomposition mechanism of $\mathrm{N}_{2} \mathrm{O}$ is proposed. These results will be critical for the design of new highly active catalysts and offer insight into the decomposition process of $\mathrm{N}_{2} \mathrm{O}$.

\section{References}

[1] X. Y. Zhao, Y. Cong, F. Lv, L. Li, X. D. Wang, T. Zhang, Chem. Commun., 2010, 46, 3028-3030.

[2] F. Kapteijn, J. Rodriguez-Mirasol, J. A. Moulijn, Appl. Catal. B, 1996, 9, 25-64.

[3] L. Xue, H. He, C. Liu, C. B. Zhang, B. Zhang, Environ. Sci. Technol., 2009, 43, 890-895.

[4] Q. Shen, L. Y. Zhang, M. F. Wu, H. Wang, N. N. Sun, W. Wei, Y. H. Sun, Mater. Res. Bull., 2017, 87, 1-5.

[5] G. Grzybek, P. Stelmachowski, S. Gudyka, J. Duch, K. Ćmil, A. Kotarba, Z. Sojka, Appl. Catal. B, 2015, 168-169, 509-514.

[6] J. A. Z. Pieterse, S. Booneveld, R. W. van den Brink, Appl. Catal. B, 2004, 51, 215-228.

[7] X. Y. Zhao, Y. Cong, Y. Q. Huang, S. Liu, X. D. Wang, T. Zhang, Catal. Lett., 2011, 141, 128-135.

[8] J. Lin, L. Li, X. L. Pan, X. D. Wang, Y. Cong, T. Zhang, S. M. Zhu, AIChE

\section{Graphical Abstract}

Chin. J. Catal., 2018, 39: 1189-1193 doi: 10.1016/S1872-2067(18)63077-3

Superior performance of iridium supported on rutile titania for the catalytic decomposition of $\mathrm{N}_{2} \mathrm{O}$ propellants

Shuang Liu, Nanfang Tang, Qinghao Shang, Chuntian Wu, Guoliang Xu, Yu Cong*

Dalian Institute of Chemical Physics, Chinese Academy of Sciences;

Shanghai Institute of Organic Chemistry, Chinese Academy of Sciences;

University of Chinese Academy of Sciences

An $\mathrm{Ir} / \mathrm{r}-\mathrm{TiO}_{2}$ catalyst exhibits high activity for the decomposition of high concentration $\mathrm{N}_{2} \mathrm{O}$, which is promising as a green propellant. Highly dispersed Ir particles and easy transfer of oxygen were critical for the decomposition process via bridge-bonded peroxide intermediates.

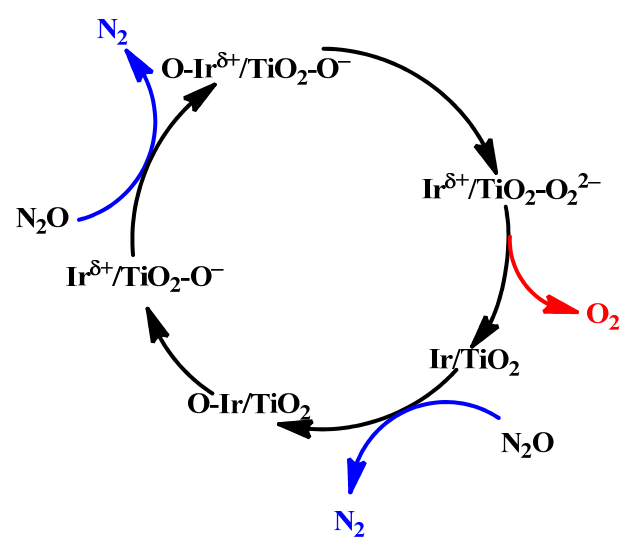


J., 2016, 62, 3973-3981.

[9] C. D. Huang, Y. Y. Zhu, X. D. Wang, X. Liu, J. H. Wang, T. Zhang, J. Catal., 2017, 34, 9-20.

[10] Z. Y. Huang, Z. G. Gao, S. M. Gao, Q. Y. Wang, Z. Y. Wang, B. B. Huang, Y. Dai, Chin. J. Catal., 2017, 38, 821-830.

[11] L. Cisneros, P. Serna, A. Corma, Chin. J. Catal, 2016, 37, 1756-1763.

[12] S. Wendt, P. T. Sprunger, E. Lira, G. K. H. Madsen, Z. S. Li, J. O. Hansen, J. Matthiesen, A. Blekinge-Rasmussen, E. Laegsgaard, B. Hammer, F. Besenbacher, Science, 2008, 320, 1755-1759.

[13] J. Lin, H. Y. Chen, L. Chen, K. L. Tan, H. C. Zeng, Appl. Surf. Sci, 1996, 103, 307-314.

[14] X. Bokhimi, R. Zanella, C. Angeles-Chavez, J. Phys. Chem. C, 2010, 114, 14101-14109.

[15] S. Liu, Y. Cong, Y. Q. Huang, X. Y. Zhao, T. Zhang, Catal. Today, 2011, $175,264-270$.
[16] E. Pachatouridou, E. Papista, A. Delimitis, M. A. Vasiliades, A. M. Efstathiou, M. D. Amiridis, O. S. Alexeev, D. Bloom, G. E. Marnellos, M. Konsolakis, E. Iliopoulou, Appl. Catal. B, 2016, 187, 259-268.

[17] H. Rojias, G. Borda, P. Reyes, J. J. Martínez, J. Valencia, J. L. G. Fierro, Catal. Today, 2008, 133-135, 699-705.

[18] J. Lin, B. T. Qiao, L. Li, H. L. Guan, C. Y. Ruan, A. Q. Wang, W. S. Zhang, X. D. Wang, T. Zhang, J. Catal., 2014, 319, 142-149.

[19] F. D. Liu, H. He, Y. Ding, C. B. Zhang, Appl. Catal. B, 2009, 93, 194-204.

[20] Y. L. Wang, Z. G. Lei, B. H. Chen, Q. H. Guo, N. Liu, Appl. Surf. Sci., 2010, 256, 4042-4047.

[21] W. B. Tolman, Angew. Chem. Int. Ed., 2010, 49, 1018-1024.

[22] M. H. Shao, P. Liu, R. R. Adzic, J. Am. Chem. Soc., 2006, 128, 7408-7409.

[23] N. Sivasankar, W. W. Weare, H. Frei, J. Am. Chem. Soc., 2011, 133, 12976-12979.

\title{
金红石型氧化钛负载的铱在催化分解 $\mathrm{N}_{2} \mathrm{O}$ 推进剂反应中的应用
}

\author{
刘 爽 ${ }^{\mathrm{a}, \mathrm{b}, \dagger}$, 唐南方 ${ }^{\mathrm{a}, \dagger}$, 商庆浩, ${ }^{\mathrm{a}, \mathrm{c}}$, 吴春田 ${ }^{\mathrm{a}}$, 许国梁 ${ }^{\mathrm{a}}$, 丛 昱, ${ }^{\mathrm{a}}{ }^{*}$ \\ ${ }^{a}$ 中国科学院大连化学物理研究所, 辽宁大连 116023 \\ b 中国科学院上海有机化学研究所, 上海 200032 \\ c中国科学院大学, 北京 100049
}

摘要: 氧化亚氮 $\left(\mathrm{N}_{2} \mathrm{O}\right)$ 是一种性能独特优越的新型绿色推进剂, 分解后可以生成高温富氧燃气, 实现自增压式多种模式推 进, 是小卫星推进系统理想的推进剂选择, 因而具有广阔的应用前景. 在标准状态下, $\mathrm{N}_{2} \mathrm{O}$ 热分解反应活化能为 $250 \mathrm{~kJ} / \mathrm{mol}$, 致使其非催化热分解温度高达 $600{ }^{\circ} \mathrm{C}$, 显然小卫星的能源系统无法满足, 必须采取催化分解的手段, 改变反应路径、降低反 应活化能, 使 $\mathrm{N}_{2} \mathrm{O}$ 能够在较低的温度下分解.

有关 $\mathrm{N}_{2} \mathrm{O}$ 分解催化剂的报道很多, 如纯相或复合氧化物、金属交换分子笁和负载贵金属等, 但是这些催化剂仍然存在 活性较低等问题, 难以满足 $\mathrm{N}_{2} \mathrm{O}$ 推进系统的应用需求. 氧化钛是光催化和金催化常用的催化剂, 经还原后能够形成氧缺陷, 可以为涉氧反应提供电子, 而 $\mathrm{N}_{2} \mathrm{O}$ 分解会产生大量氧, 氧脱附是其速率控制步骤, 因而以氧化钛为载体, 有望促进氧脱附及 $\mathrm{N}_{2} \mathrm{O}$ 分解. 与此同时, 氧化铱具有较高的 $\mathrm{N}_{2} \mathrm{O}$ 分解活性, 而且与金红石型氧化钛晶格相似, 相似的晶格参数可能会促进其在 氧化钛表面的分散, 进一步提高 $\mathrm{N}_{2} \mathrm{O}$ 分解性能. 基于此, 本文以金红石氧化钛 $\left(\mathrm{r}-\mathrm{TiO}_{2}\right)$ 为载体, 采用匀相沉积沉淀法制备了 不同载量的金红石氧化钛负载铱催化剂 $\left(\mathrm{Ir} / \mathrm{r}-\mathrm{TiO}_{2}\right)$, 并制备了锐钛矿型氧化钛、混合晶相 $\mathrm{P} 25$ 和 $\gamma-\mathrm{Al}_{2} \mathrm{O}_{3}$ 负载铱催化剂作为对 比.

通过活性测试我们发现, $\mathrm{Ir} / \mathrm{r}-\mathrm{TiO}_{2}$ 催化剂显示了非常优异的 $\mathrm{N}_{2} \mathrm{O}$ 分解活性, $\mathrm{N}_{2} \mathrm{O}$ 转化率明显高于参比催化剂, 在 $250{ }^{\circ} \mathrm{C}$ 就能够开始分解, 在 $300{ }^{\circ} \mathrm{C}$ 可以分解完全, 而且当 Ir含量降低到 $0.1 \%$ 时, 催化剂仍然保持与 $2 \mathrm{wt} \% \mathrm{Ir} / \gamma-\mathrm{Al}_{2} \mathrm{O}_{3}$ 相当的催化活 性.

随后我们采取多种表征手段对 $\mathrm{Ir} / \mathrm{r}-\mathrm{TiO}_{2}$ 的活性本质和 $\mathrm{N}_{2} \mathrm{O}$ 分解机理进行了探究. 首先利用BET、HAADF-STEM和XRD 对催化剂的基本物性进行了测试, 发现 $\mathrm{Ir} / \mathrm{r}-\mathrm{TiO}_{2}$ 具有较低的比表面积, 但金属铱在金红石氧化钛表面表现出较高的分散度, 平均粒径仅为 $1.25 \mathrm{~nm}$. 采用 $\mathrm{H}_{2}$-TPR和O $1 \mathrm{~s}$ XPS考察了催化剂的电子特性和还原特性, 发现 $\mathrm{Ir} / \mathrm{r}-\mathrm{TiO}_{2}$ 催化剂上高分散的 $\mathrm{Ir}$ 与 氧的结合能较弱, 易于还原, 有助于 $\mathrm{N}_{2} \mathrm{O}$ 的分解和生成氧的脱附. 进一步采用原位 $\mathrm{N}_{2} \mathrm{O}-\mathrm{DRIFT}$ 对 $\mathrm{N}_{2} \mathrm{O}$ 分解过程进行了研究, 发现了桥式过氧物种, 并据此提出了 $\mathrm{N}_{2} \mathrm{O}$ 在 $\mathrm{Ir} / \mathrm{r}-\mathrm{TiO}_{2}$ 催化剂上的分解机理.

关键词: 多相催化; 氧化亚氮; 催化分解; 铱催化剂; 二氧化钛

收稿日期: 2018-03-12. 接受日期: 2018-04-09. 出版日期: 2018-07-05.

*通讯联系人. 电子信箱: ycong@dicp.ac.cn

†共同第一作者.

基金来源：国家自然科学基金(21476229, 21376236, 21503264).

本文的电子版全文由Elsevier出版社在ScienceDirect上出版(http://www.sciencedirect.com/science/journal/18722067). 